\title{
Exploring the potential transition from strategic technology partnering to mergers and acquisitions
}

Citation for published version (APA):

Hagedoorn, J., \& Sadowski, B. (1995). Exploring the potential transition from strategic technology partnering to mergers and acquisitions. MERIT, Maastricht Economic Research Institute on Innovation and Technology. MERIT Research Memoranda No. 012 https://doi.org/10.26481/umamer.1995012

Document status and date:

Published: 01/01/1995

DOI:

10.26481/umamer.1995012

Document Version:

Publisher's PDF, also known as Version of record

\section{Please check the document version of this publication:}

- A submitted manuscript is the version of the article upon submission and before peer-review. There can be important differences between the submitted version and the official published version of record.

People interested in the research are advised to contact the author for the final version of the publication, or visit the DOI to the publisher's website.

- The final author version and the galley proof are versions of the publication after peer review.

- The final published version features the final layout of the paper including the volume, issue and page numbers.

Link to publication

\footnotetext{
General rights rights.

- You may freely distribute the URL identifying the publication in the public portal. please follow below link for the End User Agreement:

www.umlib.nl/taverne-license

Take down policy

If you believe that this document breaches copyright please contact us at:

repository@maastrichtuniversity.nl

providing details and we will investigate your claim.
}

Copyright and moral rights for the publications made accessible in the public portal are retained by the authors and/or other copyright owners and it is a condition of accessing publications that users recognise and abide by the legal requirements associated with these

- Users may download and print one copy of any publication from the public portal for the purpose of private study or research.

- You may not further distribute the material or use it for any profit-making activity or commercial gain

If the publication is distributed under the terms of Article $25 \mathrm{fa}$ of the Dutch Copyright Act, indicated by the "Taverne" license above, 
Exploring the potential transition from strategic technology partnering to mergers and acquisitions

John Hagedoorn and Bert Sadowski

September 1995

MERIT, Faculty of Economics and Business Administration, University of Limburg, P.O. Box 616, 6200 MD Maastricht (Netherlands) - telephone (31)43-883897-fax: (31)43-216518 


\section{Exploring the potential transition from strategic technology partnering to mergers and acquisitions}

This paper studies a number of research topics derived from the basic question: do inter-firm partnerships with different intermediary modes of company organization change over time as one of the companies that were previously cooperating becomes integrated by its partner? As such this contribution addresses the rather 'strong' variant in such a transformation process where companies are merged or taken over instead of a transformation of an equity agreement in which one of the partners increases its share in the equity distribution of an alliance. The present analysis is limited to the group of strategic technology alliances, i.e. those inter-firm agreements for which joint technology development or technology sharing are part of the agreement.

The paper first explores the literature that refers to the possible transition within strategic technology alliances from contractual to equity modes and from cooperation through alliances to mergers and acquisitions. Based on this we formulate a number of hypotheses regarding the change in modes of governance and several dimensions such as size of firms, international distribution and industry specificity. The empirical analysis employs two large data sets, one on strategic technology alliances and one on mergers and acquisitions. The major finding of our research is that the transformation from strategic technology alliance to merger and acquisition hardly ever takes place. This suggests that alliances and mergers and acquisitions are not part of a rather smooth continuum but they are first of all different modes of governance where one mode certainly does not lead to the other. 


\section{INTRODUCTION}

The present research has to be understood in the context of Williamson's (1985) well known continuum that reaches from market transactions via the 'swollen middle' (Hennart, 1993) to integrated hierarchical structures such as mergers and acquisitions. Most of the research on these alternative modes of organization has concentrated on economic or strategic implications for firms regarding each of the segments of the continuum or the trade-off in the choice between these alternatives. So far little empirical research has been performed that concerns the possible transitory aspects of different modes of company organization, e.g. the possible dynamic relationship between intermediary modes and integration. In short, this topic concerns the possible transformation of inter-firm cooperation from contractual agreements through equity agreements such as joint ventures into mergers and acquisitions.

A small number of contributions link up to the intuitive understanding of such a relationship between these different modes with an analysis that stresses an 'encroachment' strategy followed by some companies. For instance Doz, Hamel and Prahalad (1986), Haspeslagh and Jemison (1991) and Reich and Mankin (1984) analyze such strategies in the context of firms that use their strategic alliances as a vehicle to get greater control over their partners, whereby some of these partners are integrated after a period of 'courtship'. However, if we study the vast body of literature on strategic alliances, cooperative agreements, and joint ventures that has emerged parallel to the rapid increase of these inter-firm agreements, we find only very few examples where 
the encroachment thesis is empirically tested or theoretically further developed. The dynamic relationship mentioned above is only occasionally studied empirically and then usually only for some aspects. As will be discussed more extensively below some studies focus in particular on the transition from contractual alliances to joint ventures. Other contributions have some relevance for the understanding of the transition from a partnership to integration as they demonstrate some patterns in this relationship as a by-product of a study that investigates a number of adjacent research questions.

In the following we pay attention to a set of research questions related to the basic question: do inter-firm partnerships with different intermediary modes of company organization, such as contractual agreements and equity sharing agreements, change over time as one of the companies that were previously cooperating becomes integrated by its partner? This question addresses the rather 'strong' variant in the transformation process where companies are merged or taken over instead of a transformation of an equity agreement in which one of the partners increases its share in the equity distribution of an alliance. It is estimated that in the eighties and early nineties about 75\% of the strategic technology alliances are of a contractual nature without equity-sharing (Hagedoorn and Narula, 1995). Given the predominance of contractual agreements, which leaves little room for a redistribution of equity, it appears more interesting to study the possible transformation of alliances through an encroachment of partners than to concentrate on the 'weaker' variant, i.e. the increase of an equity-share in 
a joint venture.

Following the above mentioned continuum our paper concentrates on the cooperation - integration related aspects of inter-firm relationships. More specifically it studies five different modes:

- contractual agreements, in particular joint R\&D pacts and joint development agreements through which companies undertake innovative projects with shared resources

- joint ventures are combinations of the economic interests of at least two different companies in a 'distinct' firm which also performs R\&D or undertakes innovative projects

- minority holdings combined with technology transfer, where one company has taking a minority share in another company combined with technology cooperation for instance through a research contract

- take-overs or acquisitions where one company has obtained majority ownership over another company

- mergers refer to cases where two separate companies are combined into one company.

The first three modes are strategic alliances (Hagedoorn, 1993), the latter two are hierarchies in the classical sense of being modes of governance that are integrated into one company. In the present analysis we limit the group of strategic alliances to technology related partnerships, i.e. those interfirm agreements for which joint technology development or technology sharing are part of the agreement. Although this has some obvious limitations, previous research, for instance Kogut (1991), mentions the particular role that technology related 
alliances can play in possible take-over activities. In that context a strategic alliance is applied by at least one of the partners to assess the strategic importance of the technology involved. After the decision to invest in a particular technology is delayed for some time or only partially made in order to assess the importance of that technology, the company decides whether it intends to increase its activities through an acquisition of the alliance or its partner. The particular strategic importance of technology for the future competitive strength of companies is a major reason why technology related alliances are an interesting sub-set of a wider range of cooperative agreements.

In the following sections we will first explore the scattered pieces of literature that refer to the possible transition within strategic technology alliances from contractual to equity modes and from cooperation through alliances to mergers and acquisitions. Based on our understanding of the most crucial and relevant contributions we will formulate a number of hypotheses regarding the change in modes of governance and several dimensions such as size of firms, international distribution and industry specificity. Before we test the hypotheses we will pay attention to the data sets that are analyzed, the procedures used to link different data banks, and the description of the indicators as applied in this study. The section in which we report the main findings is followed by a discussion of the these findings in the light of our hypotheses. Finally, our conclusions set our contribution against the current understanding of different modes of governance and the particular 
place taken by strategic technology alliances. As our contribution has a strong exploratory character we will briefly discuss our main findings in terms of possible consequences for a theoretical understanding of strategic technology alliances as a distinct mode of governance and organization.

\section{EXPLORING THE CONTINUUM: PREVIOUS RESEARCH AND HYPOTHESES Contractual agreements leading to joint ventures}

The first possible step in the transition process of modes of governance is the change-over from contractual agreements, through which companies learn to cooperate, towards more integrated modes of cooperation with equity sharing in joint ventures. Harrigan (1988) characterizes inter-firm cooperation as part of 'transitional strategies', with 'project based ventures' , i.e. our category of contractual agreements, being replaced by other ventures of greater magnitude and permanence such as joint ventures. In a somewhat similar line of work Kogut (1989) suggests that prior experience of partner companies with other forms of cooperation can lead to joint ventures of the same companies. If companies have built a certain degree of trust based on their joint partnering experience they will force joint ventures that owe their stability to a history of cooperation. Contrary to the above mentioned studies Gulati (1995) found that the larger the number of prior alliances between partners the less likely it is that their current alliances are equity based. This could indicate that transitional strategies leading from contractual agreements to joint ventures are not found that 
frequently.

Hagedoorn (1993), Harrigan (1985) and Osborn and Baughn (1990) found that high-tech sectors and sectors characterized by turbulent environments such as information technology, biotechnology and new materials, which we refer to as new core technologies, are dominated by contractual strategic alliances with equity alliances playing a less important role. The research mentioned above also indicates that in more mature sectors one will find a larger share of equity-based alliances. In other words, firms operating in new core technologies are expected to have a higher propensity to engage in contractual agreements than those operating in a less high-tech environment where firms share a propensity to form equity alliances. Therefore, it will be necessary to analyze the process of transformation within the population of strategic alliances against their sectoral background. In that context the transition from contract to equity-sharing is expected to take place more frequently in those sectors where firms have a higher propensity to form equity agreements than in sectors where firms have a preference for contractual agreements as the dominant form of cooperation.

In order to test whether the transition process within a large population of strategic alliances does exist and to what extent there are sectoral specific conditions, we can formulate the following hypotheses:

la Allowing for some time-lag, contractual modes of strategic technology partnering lead to the formation of joint ventures between the same partners. 
If the transformation from contractual agreements to joint ventures occurs, one can expect that a disproportionate share of the cases of transformation will take place in other sectors than those related to the new core technologies.

\section{Strategic alliances leading to mergers and acquisitions}

The next step in a possible evolution of inter-firm partnering is that of the link between both contractual partnerships and equity-sharing agreements with mergers and acquisitions. As already mentioned above Doz, Hamel and Prahalad (1986) and Reich and Mankin (1984) mention that firms can use their strategic alliances to learn about the opportunity to achieve greater control over their partner in an acquisition. Also Haspeslagh and Jemison (1991) point at the possibilities offered by alliances to encroach a partner before it is acquired. Hurry (1993) points at the general advantages of incremental strategies through which, over time, cooperation leads to the acquisition of partners. Firms that are active in forming partnerships are expected to create alliances to learn about new opportunities or to use alliances as vehicles for acquisitions or divesture. Kogut (1991) analyses joint ventures as an option for firms that can bridge two basic alternatives, i.e. to wait before one commits resources and to demonstrate strong commitment through investment. Joint ventures are then used to asses the opportunity of a new technology or new product. After the chances of future success have become more clear the option to acquire is likely to be 
exercised.

In terms of the actual share of joint ventures or other modes of partnering being transformed into acquisitions we found only a few studies with empirical results. Berg et al (1982) found a large share of joint ventures to be transformed within a few years of operation as over 50 of these joint ventures were purchased by one of the parents. In a more recent study Longfellow Blodgett (1991), investigating a population of 270 international joint ventures, found that only for less than $30 \%$ of the joint ventures the equity distribution was not or hardly changed. This study suggests that the majority of technology joint ventures has their equity distribution changed over time as they are being acquired by one of the partners.

Following tis line of inquiry and extending the analysis from the change of equity distribution of joint ventures to the encroachment of partners through strategic alliances, we introduce the following hypothesis:

2 Strategic technology alliances play a major role in the formation of mergers and acquisition, whereby one of the companies participating in a contractual or an equity agreement is taken over and the alliance is transformed from shared to single ownership.

Our reading of the literature suggests that very little is known on the actual time-lag between establishing a strategic alliance or a joint venture and its possible acquisition. Kogut's 
(1988) study of nearly 150 joint ventures involving US firms shows that very few of them were acquired during the first year, during the following years about 25\% of the joint ventures were acquired. Given this degree of ignorance regarding possible timelags we will not formulate a hypothesis on this topic but keep it as a question as to what time-lag can be reconstructed for strategic alliances that are acquired.

\section{General conditions affecting the process of transformation}

Most of the studies mentioned above do study or understand strategic alliances in the context of a number of conditions that shape the outcome of partnering strategies. Ring and van de Ven (1992) discuss important dimensions that have to be taken into account such as market power differentials, domestic and international aspects, and the industry specific context of partnering behaviour.

\section{Market power and size of firms}

Hurry (1993) places part of his analysis of strategic partnering strategies in the context of the relationship between financially stronger and weaker firms. He expects stronger firms to take control over their alliances or acquire their weaker partners. Research by Berg, et al (1982), Hagedoorn and Schakenraad (1994) and Duysters and Hagedoorn (1995) suggests that larger firms are more active in partnering than their smaller competitors. The first mentioned contribution also hints at the possibility that in case of an unequal size distribution in a partnership, this 
alliance will probably be dissolved through a take-over. Taken together with the already mentioned encroachment thesis we can interpret these findings and suggestions for the relationship between size of companies and the transformation of strategic technology alliances as follows:

$3 a$ If the transformation from alliances to mergers or acquisitions occurs, a disproportionate share of these cases of transformation is between companies of different sizeclasses.

3b After a period of courtship through strategic technology alliances large firms acquire their smaller partners.

\section{Domestic versus international partnerships}

Several recent contributions suggest that the domestic or international character of an alliance influences the particular organizational mode being chosen. Research by Gulati (1995) and Hagedoorn and Narula (1995) indicates that international alliances are more equity oriented whereas a disproportionate share of domestic alliances are of a contractual nature. This equity-orientation of international partnering could imply that control through equity could be further increased through mergers and acquisitions. As already mentioned above a study by Longfellow Blodgett (1991) does suggest that international strategic technology alliances have a high chance of being acquired. From both a transaction cost theory perspective and a more strategic management perspective this preference can be 
explained in terms of the cost of monitoring and keeping control over a long distance agreement. As domestic alliances are formed in a familiar environment, equity control is probably less prevalent in order to monitor the agreement than in the case of international alliances. Hence:

4 If the transformation from alliances to mergers or acquisitions occurs, international alliances have a higher probability of leading to such a transformation than domestic alliances.

\section{Industry context}

Contributions by Harrigan and Newman (1990) and Balakrishna and Koza (1993) suggest that joint ventures between companies from similar businesses have a higher probability of being disolved than those made between companies from dissimilar industries. Hagedoorn (1993) discusses the importance of technological and/or market complementarity for understanding the motives of partners to engage in strategic technology alliances. If this complementarity is an essential characteristic for successfully maintaining a strategic alliance, this suggests that complementarity of partners that are operating in dissimilar product-markets with little conflict of interests increases the chances of the combined effort, whereas cooperation between companies with similar product-market combinations and a higher probability of a conflict of interests is more likely to be resolved in a take-over. Therefore: 
12

5 If the transformation from alliances to mergers or acquisitions occurs, strategic technology alliances between companies from the same industry have a higher chance of being part of a take-over or merger transformation than alliances between companies from different sectors.

A number of studies reveals that the level of technological sophistication of sectors of industry affects the distribution of equity or non-equity modes of strategic technology partnering. According to Harrigan (1985 and 1988) rapid technological change in sectors of industry induces the formation of somewhat informal forms of cooperation such as non-equity agreements. As industries become mature, more formal modes of cooperations such as joint ventures become the preferred form of collaboration. Also Osborn and Baughn's (1990) survey of the literature suggests that technological stability of industrial sectors is a crucial factor in explaining different patterns for equity and non-equity partnerships. R\&D intensive sectors will demand more organizational flexibility leading to a general preference for contractual agreements, whereas in sectors with low degrees of R\&D intensity where organizational flexibility is less crucial, technology partnering agreements will tend to be dominated by joint ventures. Yu and Tang's (1992) findings can be interpreted along similar lines: stable sectoral environments favour joint venture formation, uncertain environments will lead to a larger number of non-equity agreements. Hagedoorn and Narula (1995) also found that high-tech sectors are characterized by a vast majority 
of contractual agreements, whereas the formation of joint ventures accounts for a disproportionate share of technology partnering in medium and low-tech industries. This preference for contractual agreements in high-tech sectors and new core technologies and equity oriented cooperation in other sectors suggests that the transformation of strategic technology alliances into mergers and acquisition could also be unevenly distributed. Hence:

If the transformation from alliances to mergers or
acquisitions occurs, the probability of such a
transformation is lower for the group of transformed
alliances in new core technologies than for the group of
alliances linked to mergers and acquisitions in other
sectors or fields of technology.

\section{DATA AND METHODOLOGY}

In order to find out to what extent strategic technology alliances lead to mergers and acquisitions we combined data from two data banks, i.e. the MERIT-CATI data bank on strategic technology alliances and the Securities Data data set on mergers and acquisitions. The MERIT CATI data bank contains data on nearly 13.000 cooperative technology agreements involving about 5.000 parent companies. The information is stored in the form of a relational database whereby its separate data files can be 
linked to each other in order to provide data in a (dis)aggregate and combined form. Preliminary data collection started in 1985. Since 1987 data on inter-firm alliances have been systematically collected, including a retrospective search, and the database currently covers the period between 1970 and 1993. Data sources include, in general, newspaper and journal articles, books dealing with the subject and, in particular, specialised trade journals. Companies' annual reports, the Financial Times' Industrial Companies Yearbooks and Dun and Bradstreet's Who Owns Whom provided information about dissolved equity ventures and investments, as well as ventures that we did not register when surveying alliances.

The database contains information on each cooperative agreement and some information on companies participating in these agreements. Cooperative agreements are defined as the establishment of common interests between independent (industrial) partners which are not connected through (majority) ownership. The transfer of technology or the undertaking of joint research is considered as crucial to these arrangements. Examples in this respect are joint research pacts and joint development agreements. In addition data are collected on joint ventures with technology sharing or which have a joint $R \& D$ program. Mere production or marketing joint ventures are excluded.

For the purpose of the present analysis information is used regarding the form of cooperation, the 'nationality' and the size of firms involved, the sectors and fields of technology and the year of establishment of the cooperative agreement. Within the 
CATI database the form of cooperation is distinguished according to equity and non-equity (contractual) arrangements. The 'nationality' of firms has been classified with respect to the location of the headquarters of the enterprise. The distribution of firm size is according to employment in five categories (less than 500, 500 to $5.000,5.000$ to $50.000,50.000$ to 150.000, larger than 150.000 employees). Within the CATI database there are 65 classifications with respect to sectors and fields of technology. A major distinction is made between new core technologies (information technologies, biotechnology, new materials) and other industrial sectors. Additional information on this data bank can be found in Hagedoorn (1993) and Hagedoorn and Schakenraad (1994), or obtained from the authors.

The second data bank provides information on mergers and acquisitions. This data bank is property of the firm securities Data and can be used via on-line access. Currently it contains information on about 125.000 worldwide mergers and acquisitions for the period 1980-1994. This information is arranged in several data files. For a limited period of time this data base has been accessed and a specific data sample has been extracted. The relational form of the data base facilitates the linking of these data files to each other and also to files in other data banks. Within the mergers and acquisitions data base there is information on the different modes of acquisition and the year of acquisition. In addition, it contains company information on the acquiror, the target, the parent acquiror and the parent target firm. The industry information is provided in SIC codes of the aquiree and acquiror. Unfortunately, the distinction on different 
modes of acquisition (merger, minority holding, etc.) as made by Securities Data does not always correspond to the real background of the acquisition. This is partly due to the character of information on mergers and acquisition in the trade literature. For example, a number of cases has been classified as mergers despite the obvious mis-matches in firm-size indicating an acquisition. Also, acquisitions are frequently presented as mergers because of the negative publicity that acquisitions receive in particular if a foreign partner is involved. As mergers and acquisitions both lead to integration they are taken together and considered as one single category.

For the search procedure that would allow us to find any transition from strategic technology alliances to mergers and acquisitions we have taken the following steps:

- First, a search procedure was developed that would guarantee that all partnering firms involved in a strategic alliance and/or a merger or acquisition in both data banks could be identified. The actual search procedure applied examined the parent companies involved in a strategic technology alliance and/or a merger or acquisition. This procedure ensures the highest level of corporate control for the analysis with all subsidiaries that are part of a strategic technology alliance or a merger or acquisition being included.

- Second, a correspondence in the data fields concerning industry information in both data banks had to be made at the industry level. The technology classification in the CATI data based was adjusted to the SIC code system in the mergers and acquisitions data base using a correspondence 
table. As a result, the data on cooperative technology alliances within the CATI data bank relevant to the analysis amounted to 6060 strategic technology partnerships. The extracted amount of data from the database on mergers and acquisitions corresponding to the CATI data bank amounted to approximately 16,400 cases. In total about 1900 companies are involved in either strategic technology alliances or mergers and acquisitions during the period under consideration.

- Finally, to examine the probability of a transition from strategic technology alliances to mergers or acquisitions, the sub-set of data extracted from the CATI database is used as the starting point for the analysis. A time lag between one and ten years is used in order to avoid that minority holdings and joint ventures were counted twice in the CATI and in the mergers and acquisitions data bank.

The population of strategic technology alliances under transition was examined with respect to different determinants that affect this transition. Following the hypotheses discussed above, these determinants are sectors and fields of technology, size of firms involved, and the international character of partnerships. The results of the examination of these different determinants are set against the total population of strategic technology alliances corresponding to the mergers and acquisitions database. As will become clear from the empirical analysis in the following sections, the testing of the hypotheses can be limited to simple statistics. 


\section{EMPIRICAL FINDINGS}

The first step in our analysis is the transformation from contractual agreement to joint ventures with which we remain within the domain of strategic technology alliances. Out of a total of 6060 relevant strategic technology alliances in the MERIT-CATI data bank we found only 84 cases in which a contractual agreement led to a joint venture (see table 1). If this intra-partnership transformation took place, the time-lag was less than 5 years for $76 \%$ of these cases, for $26 \%$ the transformation took place within 1 year. As far as the sectoral distribution is concerned nearly 75\% of these cases took place in the new core technologies, whereas the overall share for these core technology alliances is about 66\% (see table 1). A simple chi-square test reveals that there is a significant difference between both distributions ( $X^{2}=4.6477$; significance 0.0311$)$.

We now proceed with the analysis of the transformation from both contractual and equity based technology alliances to mergers and acquisitions. From the total of 6060 strategic technology alliances only 143 cases (or about 2.3\% of all relevant alliances) could be linked to mergers and or acquisitions of identical partners. If this transition from strategic technology partnership to merger or acquisition took place, this happened for $64 \%$ of these cases within a relatively short period of 5 years after the partnership was established. 
Table 2 presents some size-related characteristics of firms involved with strategic technology alliances that have led to mergers and acquisitions of partners. About 45\% of the firms involved in this transformation process employ between 5,000 and 50,000 people. The group of large firms with over 50,000 employees have a share of about 19\% of this particular group of alliances. Compared to the overall distribution of the 6060 alliances that we searched in this study the distribution for alliances in transition is somewhat more skewed as firms with over 5,000 employees have a share of $71 \%$ against $34 \%$ for all alliances. If we consider the distribution of partners from similar or dissimilar size-categories also involved in a merger or acquisition succeeding a strategic alliance we see that about two-third of these alliances are made between dissimilar companies. However, for the total of strategic technology alliances the share of companies from different size-classes is higher as about 77\% of the partnerships are made between dissimilar firms. Set against the total number of 143 alliances leading to mergers and acquisitions only about 16\% refer to cases where a large or very large company acquires its smaller partner.

Data regarding the (inter) national and sectoral patterns of the group of strategic technology alliances leading to mergers 
and acquisitions is presented in table 3. Apparently the distribution of domestic and international alliances is not that unequal, although we do see a slightly higher share for international alliances. If we compare this distribution to the overall population of strategic technology alliances we see that the two sub-sets are somewhat different as 58\% of the alliances in the overall population are international. The chi-square test reveals that there is no significant difference between both distributions $\left(X^{2}=2.4701\right.$; significance 0.1160$)$.

If we look at the sectoral background of companies participating in these transitory strategic technology alliances (table 3) we see that about $64 \%$ of them are made by companies from the same sectors compared to 49\% for the overall population of strategic technology alliances. The chi-square test reveals that there are significant differences between both distributions $\left(X^{2}=10.6253 ;\right.$ significance 0.0011$)$.

As far as the distribution of new core technology alliances and other fields of partnering is concerned we see some interesting differences. There is a significant difference between the share for high-tech alliances preceding a take-over or merger (56\%) and the share for the population at large where 66\% of the strategic technology alliances are made in new core technologies $\left(X^{2}=6.7655\right.$; significance 0.0093$)$. 


\section{DISCUSSION}

Our findings appear to contradict some previous research findings or expectations expressed in a large part of the theoretically relevant literature. Most of the hypotheses, whether they relate to the relevance of these transformation processes or the characteristics of the firms and alliances involved, are falsified. The results are particularly strong as we used two large data sets combining information on over 6000 strategic technology alliances with information on 16,000 mergers and acquisitions of the same group of 1900 firms.

As far as the changes within strategic technology alliances are concerned only very few contractual agreements are actually turned into joint ventures. Apparently, the transition from contractual agreement to joint venture (hypothesis la) does not play any role of importance in inter-firm strategic technology partnering. For the relatively small number of cases where this transition did take place the sectoral distribution (hypothesis 1b) demonstrates that, contrary to what was expected, the share of non-core technologies is higher in the overall population. It does not seem that this phenomenon of transition into equity alliances is particularly well spread in sectors where otherwise equity partnerships are more apparent. In other words, if there is a disproportionate preference for equity-based alliances in the somewhat more mature sectors, companies forge these partnerships without a clear preference for a transitory approach where contractual alliances are being remoulded into equity arrangements. In all of this it is important to understand that the growth of strategic alliances since the early $1980 \mathrm{~s}$ is in 
particular affected by the growth of contractual agreements. Hagedoorn and Narula (1995) mention that during the early seventies about 75\% of the alliances were joint ventures, in the early nineties the distribution has been completely reversed with 75\% of the alliances being of a contractual nature. Contractual agreements have become the dominant form of strategic technology partnering and are to be seen as a mode of cooperation sui generis and not a simple transitory stage towards equity sharing. Turning to the thrust of this paper the analysis of the process of transformation from strategic technology partnering to mergers and acquisition it is clear that strategic technology partnering plays hardly any role in the process of acquisition and mergers (hypothesis 2). Only about 2.3\% of the relevant 6060 technology alliances related to companies that are active in technology partnering as well as in mergers and acquisitions.

Given the small number of cases in which the transformation did take place the statistical analysis had to remain extremely simple. Also, all findings that provide some understanding of the transformation process have to be clearly placed against the background of the limited relevance that this process apparently has. Nevertheless, our findings regarding some of the characteristics of the alliances and the firms involved are interesting as they falsify some hypotheses generated in the literature as well as some intuitive understanding.

Concerning the dissimilarity of size-classes of companies that use strategic technology alliances to acquire their partners or merge with them (hypothesis 3a), it does seem that, as expected, a majority of two-third of these companies are 
complementary in terms of their size. However, set against a similar distribution for all relevant strategic technology partnering this size-complementarity is smaller than expected. In that context we also found little support for an encroachment thesis with large firms using their strategic technology alliances to take over their small partners (hypothesis 3b). The role of large firms in taking over their smaller partners is rather limited as this happened in about 16\% of the cases where strategic technology alliances were transformed into integrated common ownership.

Given the strategic and cost implications of control over strategic technology alliances one could expect that companies have a higher preference for taking over their international partners than those with which they share domestic alliances (hypothesis 4). Somewhat surprisingly we found a close to a fifty-fifty distribution for acquired partners from domestic versus international alliances which is, however, not significantly different from the overall distribution where a majority of 58\% is of an international nature. Apparently partners in international strategic technology alliances do not necessarily run a higher risk of being acquired than if they form domestic alliances.

If complementarity of partners is a major incentive to form alliances one could expect that similar sectoral backgrounds of companies will lead to conflicting interests as companies are both cooperating and competing in similar or closely related product-markets. Therefore, the probability of an acquisition or a merger after an initial stage of partnering was expected to be 
higher for partnering companies from the same sector (hypothesis 5). Indeed, there are significant differences with the overall distribution suggesting that alliances that are transformed into mergers and acquisitions companies do not follow the more general pattern (Hagedoorn, 1993; Harrigan, 1985; Mowery, 1988; Ohmae, 1985) that demonstrates a preference for complementary partners from other sectors or fields of technology.

In the overall distribution of strategic technology alliances new core technologies take a dominant position with nearly two-thirds of all alliances being related to these new technologies. As discussed above, once technological development becomes less turbulent and related industrial structures become more stable equity-sharing could become more important in the formation of alliances. Following this line of thought we can expect alliances that are part of a process of merger and acquisition to be also less focused on high-tech cooperation (hypothesis 6). Indeed, our findings suggest that a relatively large and disproportionate share (44\%) of strategic technology alliances that are preceding a merger or acquisition of identical companies are related to more standard technology exchange and less involved in new core technology partnering.

\section{CONCLUSIONS}

It is important to stress a particular limitation of this paper which is that our research pertains to only one specific group of alliances, i.e. those for which the sharing or joint development of new technologies and joint undertaking of $R \& D$ is part of the 
alliance. Therefore, our results have probably few implications for those strategic alliances aimed at joint marketing or the sharing of manufacturing or services. However, in recent years a growing number of contributions (Hagedoorn and Schakenraad, 1994; Osborn and Baughn, 1990; Mowery, 1988; Mytelka, 1991) stress the importance that strategic alliances with a large technology content play in turbulent high-tech industries that will shape much of the present and near-future competitive environment. It is also in these industries that we find a dominance of contractual modes of partnering.

These strategic technology alliances have to be understood as an important part of a learning process of companies in which they discover new innovative opportunities in a flexible setting of a multitude of partnerships (Ciborra, 1991; Hagedoorn, 1995). Such a learning process in the context of cooperative technological development is of a complicated nature that resembles high-tech learning (Lyles, 1994), exploratory learning (Dodgson, 1993; March, 1991) or double-loop learning (Argyris and Schon, 1978) as it covers a change of routines, unlearning and the discovery of new issues in a joint effort. To some extent the complexity of this learning is due to partner differences (Parkhe, 1991). However, this complexity is at least as much influenced by the exploratory nature of learning in technological development itself, in particular in those industries where technological change is still of a turbulent nature.

Once this learning process of companies changes towards more standard information processing and learning and flexibility become less important for large groups of companies as industries 
gradually mature, integration through mergers and acquisitions will probably become a more viable option (Ciborra, 1991). As long as sectors of industry or fields of technology can be characterized as turbulent environments with high technological risk (Ring and van de Ven, 1992) combinations of internal learning and the timely absorption of new technologies through alliances can be more effective than take-overs or mergers of (parts of) companies. In other words, for technological renewal under dynamic-competitive circumstances (Garud, 1994) where knowledge expires quickly, flexible partnering with capable partners might be more adequate than an encroachment strategy leading to formal integration.

In the few cases where strategic technology partnering is part of a movement along the continuum from contractual and equity-sharing agreements to mergers or acquisition, it seems this pattern defies the logic that one could deduct from scattered pieces of literature on joint ventures and strategic partnering that point at the relevance of an 'encroachment' strategy. For instance, large firms are known to be very active in the market for take-overs and mergers and also in strategic technology partnering but the latter seems to be applied by them for other purposes than as part of a transitional strategy. They certainly do not extensively use these alliances to integrate their smaller partners.

A major conclusion from this study appears to be that strategic technology partnering is a different category on its on. In evaluating the impact of strategic decisions in the context of integration versus contracting strategies aimed at 
improving the innovative capabilities of firms (Teece, 1987) there appears to be little room for transitional strategies. Separate modes of partnering, be it of a contractual or an equity nature, have different organizational and strategic properties (Hagedoorn, 1993) but they share their distinctive character that sets them apart from common governance through integration. In that sense, there exists, as far as strategic technology partnering is concerned, and with very few exceptions, no real continuum which suggests that strategic cooperation is a 'front porch' for corporate growth through integration. 


\section{REFERENCES}

Argyris, C. and D.A. Schon, 1978, organizational learning, Reading MA, Addison-Wesley.

Balakrishnan, S. and M.P. Koza, 1993, Information asymmetry, adverse selection and joint ventures - theory and evidence, Journal of Economic Behavior and Organization, 20, pp. 99-117.

Berg, S.V., J. Duncan and P. Friedman, 1982, Joint venture strategies and corporate innovation, Cambridge, Oelgeschlager, Gunn \& Hain.

Ciborra, C., 1991, Alliances as learning experiments: cooperation, compettion and change in high-tech industries, in L.K. Mytelka (ed.), Strategic partnerships and the world economy, London, Pinter, pp. 51-77.

Dodgson, M., 1993, Organizational learning: a review of some literatures, Organization Studies , 14, pp. 375-394.

Doz, Y., G. Hamel and C.K. Prahalad, 1986, Strategic partnerships: Success or surrender?, University of Michigan Working Paper.

Duysters, G. and J. Hagedoorn, 1995, Strategic groups and interfirm networks in international high-tech industries, Journal of Management studies, 32, pp .361-381. 
Garud, R., 1994, Cooperative and competitive behaviors during the process of creative destruction, Research Policy, 23, pp. 385394 .

Gulati, R., 1995, Does familiarity breed trust? The implications of repeated ties for contractual choice in alliances, Academy of Management Journal, 38, pp. 85-112.

Hagedoorn, J., 1993, Understanding the rationale of strategic technology partnering: inter-organizational modes of cooperation and sectoral differences, Strategic Management Journal, 14, 371385.

Hagedoorn, J., 1995, A note on international market leaders and networks of strategic technology partnering, strategic Management Journal, 16, pp. 241-250.

Hagedoorn, J. and R. Narula, 1995, Choosing modes of governance for strategic technology partnering: international and sectoral differences, to be published in Journal of International Business Studies.

Hagedoorn, J. and J. Schakenraad, 1994, The effect of strategic technology alliances on company performance, Strategic Management Journal, 15, pp.291-311.

Harrigan, K.R., 1985, Strategies for joint ventures, Lexington, Lexington Books. 
Harrigan, K.R., 1988, Joint ventures and competitive strategy, Strategic Management Journal, 9, pp. 141-158.

Harrigan, K.R. and W.H. Newman, 1990, Bases of interorganization co-operation: propensity, power, persistence, Journal of Management Studies, 27, pp. 417-434.

Haspeslagh, P. and D. Jemison. 1991, Managing acquisitions: creating value through corporate renewal, New York, Free Press.

Hennart, J-F, 1993, Explaining the swollen middle: why most transactions are a mix of 'market' and 'hierarchy', organization Science, 4, pp. 529-547.

Hurry, D., 1993, Restructuring in the global economy; the consequences of strategic linkages between Japanese and U.S. firms, Strategic Management Journal, 14, pp. 69-82.

Kogut, B., 1989, The stability of joint ventures: reciprocity and competitive rivalry, Journal of Industrial Economics, 38, pp. $183-193$.

Kogut, B., 1991, Joint ventures and the option to expand and acquire, Management Science, 37, pp. 19-33.

Longfellow Blodgett, L., 1991, Partner contributions as predictors of equity share in international joint ventures, Journal of International Business Studies, 22, pp. 63-78. 
Lyles, M.A., 1994, The impact of organizational learning on joint venture formations, International Business Review, 4, pp. 459467 .

March, J.G., 1991, Exploration and exploitation in organizational learning, organizational Science, 2, pp. 71-87.

Mowery, D.C. (ed.), 1988, International collaborative ventures in U.S. manufacturing, Cambridge, Ballinger.

Mytelka, L.K. (ed.), 1991, Strategic partnerships and the world economy, London, Pinter.

Ohmae, K., 1985, Triad power, New York, Free Press.

Osborn, R.N. and C.C. Baughn, 1990, Forms of interorganizational governance for multinational alliances, Academy of Management Journal, 33, pp. 503-519.

Parkhe, A., 1991, Interfirm diversity, organizational learning, and longevity in global strategic alliances, Journal of International Business Studies, 22, pp. 579-601.

Reich, R. B. and E.D. Mankin, 1984, Joint ventures with Japan give away our future, Harvard Business Review, March- April, pp. $78-86$.

Ring, P.S. and A.H. van de Ven, 1992, Structuring cooperative 
relationships between organizations, Strategic Management Journal, 13, pp. 483-498.

Teece, D.J., 1987, Profiting from technological innovation: implications for integration, collaboration, and public policy, in D.J. Teece (ed.), The competitive challenge, Cambridge (Ma.), Ballinger.

Williamson, O.E., 1975, Markets and hierarchies: Analysis and anti-trust implications, New York, The Free Press.

Yu, C-M. J. and M-J. Tang, 1992, International joint ventures: theoretical considerations, Managerial and Decision Economics, 13, pp. $331-342$. 
Table 1 Distribution of contractual technology alliances transformed into joint ventures $\left(n_{1}=84\right)$, overall distribution of strategic technology alliances $\left(\mathrm{n}_{2}=\right.$ 6060), core technologies and other sectors, 1970 - 1993

Transformed alliances All alliances

Core technologies

$74.2 \%$

$66.4 \%$

Other sectors

$25.8 \%$

$100 \%$

Total

$X^{2}=4.6477 ;$ significance 0.0311

Source: MERIT-CATI
$33.6 \%$

$100 \%$ 
Table 2 Company-size related characteristics of strategic technology alliances transformed into mergers and acquisitions, 응 1970-1993

Size distribution Companies in transformed alliances

$$
\left(\mathrm{n}_{1}=168\right)
$$

< 500 employees

$500-5000$

$5000-50.000$

$50.000-150.000$

$>150.000$

Total

Alliances with

companies of:

similar size

dissimilar size

- of which dominated

by large firms*

Transformed alliances

$$
\left(\mathrm{n}_{1}=143\right)
$$

$32.5 \%$

$67.5 \%$

$16.3 \%$
Companies in

all alliances

$$
\left(\mathrm{n}_{2}=1893\right)
$$

$38.1 \%$

$27.5 \%$

$26.0 \%$

$6.1 \%$

$2.3 \%$

$100 \%$

All alliances

$\left(\mathrm{n}_{2}=6060\right)$

$22.7 \%$

$77.3 \%$

$X^{2}=6.7126$; significance 0.0096 for distributions of (dis) similar size

*large firm dominance: combinations of firms >150.000 employees with all companies $<50.000$ employees; companies with between 50.000 - 150.000 employees with all companies <5.000 employees Source: MERIT-CATI and Securities Data - M\&A 
Table 3 International and sectoral patterns in strategic technology alliances transformed into mergers and acquisitions, $1970-1993$

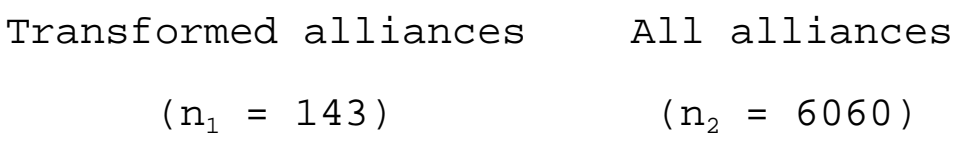

Domestic alliances

International alliances

Total

Identical sectors

Different sectors

Total

Core technologies

Other sectors

Total
$48.3 \%$

$51.7 \%$

$100 \%$

$64.2 \%$

$35.8 \%$

$100 \%$

$56.0 \%$

$44.0 \%$

$100 \%$
$41.8 \%$

$58.2 \%$

$100 \%$

$49.3 \%$

$50.7 \%$

$100 \%$

(Inter-)national distribution, $X^{2}=2.4701$; significance 0.1160

Identical sectors distribution, $X^{2}=10.6253 ;$ significance 0.0011

Core technologies distribution, $X^{2}=6.7655$; significance 0.0093

Source: MERIT-CATI and Securities Data - M\&A 